\title{
When "Creeping Jurisdiction" Goes Awry: The Social Action Litigation to Ban Surrogacy
}

\author{
by Sital Kalantry
}

Significant scholarly attention has focused on the strong role played by the Supreme Court in the Indian constitutional democracy. Exercising its powers of judicial review, the Court will invalidate legislation if determines it to be in violation of the constitution. ${ }^{1}$ In the judicial appointments case, for example, it invalidated legislation that would have reformed the judicial appointments system. ${ }^{2}$ When there is no law, but the Court finds that certain circumstances in society violate the fundamental rights of certain groups of people, it may issue its own legislative-like guidelines. It did this in the internationally famous Vishaka case, in which it created guidelines on sexual harassment. ${ }^{3}$

In some cases, the Court may decide that it would be more effective to retain jurisdiction in a case over a long period of time and prod the executive to create policy or design legislation rather than fashion its own remedies. Professor Baxi has famously described this as "creeping jurisdiction." The Court uses creeping jurisdiction, according to Professor Baxi, when it holds numerous hearings over the course of a long period of time without dismissing the case quickly. ${ }^{5}$ The Court essentially takes over the administration of an issue or a matter to make sure that its orders to various agencies are implemented. ${ }^{6}$

The Court often exercises creeping jurisdiction in the context of "social action litigation." While the "public interest litigation" is commonly used, Professor Baxi objects to the use of that terminology because (in part) it gives too much credence to (failed) American techniques and vocabulary. ${ }^{8}$ In honor of Professor Baxi, I use the term "social action litigation" ("SAL") to describe litigation brought by impacted parties or social activists seeking redressal for a violation of their fundamental rights.

\footnotetext{
${ }^{1}$ Chintan Chandrachud, Declarations of Unconstitutionality in India and the U.K.: Comparing the Space for Political Response, 43 Ga. J. Int'l \& Comp. L. 309 at 316-17 (stating that there are four reasons the Court can declare a law unconstitutional, including that the statute might be found to breach one or more fundamental rights embodied in Part III of the Constitution and citing e.g., R.C. Cooper v. Union of India, A.I.R. 1970 S.C. 564 (India)).

${ }^{2}$ See Supreme Court Advocates-on-Record - Association \& Anr. v/s Union of India, Writ Petition (Civil) No. 13 of 2015.

${ }^{3}$ Vishaka \& Ors v. State of Rajasthan \& Ors, A.I.R. 1997 S.C. 3011 (India).

${ }^{4}$ Upendra Baxi coined the term "creeping jurisdiction" in 1985. Upendra Baxi, Taking Suffering Seriously: Social Action Litigation in the Supreme Court of India, 4 (6) Third World Legal Studies 107, 122. This can mean in terms of time (the Court keeps hold of a case through interim orders and never provides a final order) but also breadth (the Court extends its reach and orders beyond what was initially requested).

${ }^{5} \mathrm{Id}$.

${ }^{6} \mathrm{Id}$.

${ }^{7}$ Id.

${ }^{8}$ Id. at $108-111$.
} 
The heyday of SAL was the post-emergency era where the Supreme Court began to assert a role in rectifying the large-scale inequalities in Indian society. In an article published in 1985 for a global audience called "Taking Suffering Seriously: Social Action Litigation in the Supreme Court of India," Baxi gave many examples of social activists who read media stories and brought claims to the courts. For example, a Supreme Court advocate filed a writ based on a series of articles in a national daily, The Indian Express, exposing the plight of Bihar under trial prisoners. ${ }^{9}$ In another case, a reporter brought a petition about child sexual abuse in Kanpur jail. ${ }^{10}$ Professor Baxi was also actively involved in bringing SAL cases to the Court. In 1982, he assisted social workers in filing writ proceedings against the state of Madhya Pradesh for allowing bonded laborers to be paid in a food that was toxic. ${ }^{11}$

The SAL cases documented by Professor Baxi typically involve the state perpetrating human rights violations. In his words, "much of SAL focuses on exposure of repression by the agencies of the state, notably the police, prison and other custodial authorities." 12 Another category of cases, he states, are "the cases which seek to ensure that authorities of the state fulfill the obligations of law under which they exist and function." 13 Indeed, according to Baxi, "much of SAL is concerned with combating repression and governmental lawlessness."14

Some SAL cases today also fall into the category described by Baxi in 1985, but many SAL cases do not involve situations where the state has perpetrated the violation or has an obvious duty to act to prevent harm. The SAL in regard to the practice of surrogacy, where intended parents hire women to carry their children, is not like the traditional SAL cases described by Baxi. Filed in February 2015, the petition alleges that when poor women agree to carry children for other people for large sums of money, the fundamental rights of the surrogates are violated. The petition asks the Supreme Court to stop the practice. Unlike the SAL described by Professor Baxi, the government is not perpetrating or causing the alleged harm, nor is it clear what the government should do to prevent the harm-legalize and regulate surrogacy to make it fairer for surrogates to work as surrogates or ban surrogacy, which prevents poor women from improving their lives with the significant money they make.

I posit here that the surrogacy SAL reveals some of the dangers of the modern use of "creeping jurisdiction" where the judges push a normative agenda with the executive and other agencies without putting in adequate thought and consideration that would be required if they published a judgment. While its impact in changing executive policy is far from certain, circumstantial evidence suggests the Court had an important role to play in the change in the executive's policy from a permissive approach to a prohibitionist

\footnotetext{
${ }^{9}$ Id. at 116.

${ }^{10} \mathrm{Id}$. at 117.

${ }^{11}$ Id. at 117.

12 Id. at 119.

${ }^{13}$ Id. at 119.

${ }^{14}$ Id. at 119.
} 
approach to surrogacy. This role, however, is not well-documented, because many of the Courts commands were made orally from the bench, but never documented in a written order. Sitting in a two-judge bench in October 14, 2015, the Court told the executive from the bench that compensated surrogacy should be banned. ${ }^{15}$ We know this only because a reporter from the Times of India who was likely sitting in the Court published those remarks, but the written order from that day does not indicate the Court's stance against surrogacy. ${ }^{16}$

After the October 14, 2015 hearing, in what was previously one of the world's leading destinations for surrogacy, the executive unilaterally halted transnational surrogacy in November 2015. ${ }^{17}$ Thereafter, during the course of the surrogacy SAL, the executive proposed a bill regarding surrogacy in $2016 .{ }^{18}$ Of the three prior bills that had been proposed $(2008,2010$, and 2014), the bill proposed in 2016 was the first bill to ban compensated surrogacy altogether.

In Section 1 of this Chapter, I describe how the surrogacy markets grew in India without any government regulation until the executive banned transnational surrogacy and proposed a bill to also prohibit Indians from hiring and paying a woman to carry their child. In Section 2, I provide background on the surrogacy SAL, which was filed by Jayashree Wad based on media stories of abuse of surrogates, and was merged with the Jan Balaz case. That case involved the citizenship status of two German children born to an Indian surrogate. The Jan Balaz case commenced in 2009, but was resolved just before the surrogacy SAL was filed. In Section 3, I explain how the Court used creeping jurisdiction to push the executive to adopt a certain normative view about surrogacy. The Court held numerous hearings over the course of many years and hauled in executive officials, including the solicitor general, and asked them to explain what actions they

\footnotetext{
${ }^{15}$ Amit Anand Choudhary, SC Seeks Commercial Surrogacy Ban, TimeS OF INDIA, October 15, 2015, http://timesofindia.indiatimes.com/india/SC-suggests-ban-on-commercialsurrogacy/articleshow/49365734.cms.

${ }^{16}$ Supreme Court of India, Civil Appeal No. 8714/2010, Union of India \& Anr. V. Jan Balaz \& Ors., Item No. 101(PH), Court No. 8, Section IX, Oct. 14, 2015, http://supremecourtofindia.nic.in/jonew/courtnic/rop/2009/35832/rop 378475.pdf.

${ }^{17}$ Circular No. 462, Ministry of Home Affairs, Government of India (Nov. 3, 2015) (India), available at http://mha1.nic.in/pdfs/surrogacy03112015.pdf. Previously, in January 2013, the Ministry of Home Affairs had prohibited foreign gay people and single people from availing of medical and gestational care. However, Indian single individuals and gay couples continue to be able to hire a surrogate. Madhavi Rajadhyakshal, No surrogacy visa for gay foreigners, TIMES OF INDIA, Jan. 18, 2013, http://timesofindia.indiatimes.com/india/No-surrogacy-visa-for-gay-foreigners/articleshow/18066771.cms. Gay Bollywood film producer, Karan Jorar, recently made headlines for having twins from a surrogate. Parenthood through Surrogacy: Karan Johar confirms birth of twins - Roohi and Yash, INDIAN EXPRESS, Mar. 6, 2017, http://indianexpress.com/article/india/parenthood-through-surrogacy-karan-johar-confirmsbirth-of-twins-roohi-and-yash-4556163/.

${ }^{18}$ Surrogacy (Regulation) Bill, No. 257 of 2016 (India), available at http://164.100.47.4/BillsTexts/LSBillTexts/Asintroduced/257_LS_2016_Eng.pdf [hereinafter 2016 Bill]; see Cabinet approves bill to prohibit commercial surrogacy, Sushma Swaraj slams celebrities for misusing practice, THE INDIAN EXPRESS, August 25, 2016, indianexpress.com/article/india/india-newsindia/surrogacy-bill-2016-sushma-swaraj-slams-celebrities-for-misusing-practice/ [hereinafter Cabinet Approves Bill].
} 
were taking to address surrogacy. In Section 4, I explain the potential impact of the Court's directions on executive policy. Section 5 critiques the use of creeping jurisdiction in the surrogacy SAL. Section 6 analyzes the claim that surrogates are exploited and suggests that the issue is much more complicated than the Court's preliminary observations suggest.

\section{Surrogacy Markets Grow Until the Executive Bans Transnational Surrogacy}

The surrogacy market in India has flourished over the last few decades. ${ }^{19}$ Some estimate that surrogacy has generated over two billion dollars for India. ${ }^{20}$ Gay male and infertile couples flocked to India, because their own countries prohibited surrogacy and/or it was cheaper in India. India is an ideal host country for transnational surrogacyit has state-of-the-art medical tourism facilities, English-speaking medical professionals, and a relatively large supply of poor women to provide gestational care. ${ }^{21}$ I use "gestational care" to describe the services provided by a surrogate rather than words such as "rent-a-womb" which diminish women to their body parts. ${ }^{22}$ In a typical arrangement, the surrogate has no genetic relation to the child she gives birth to, but rather both intended parents are the ones that are biologically related to the child. ${ }^{23}$

The web of actors in the Indian surrogacy industry, including intended parents, medical fertility doctors, agents who recruit surrogates, and surrogates themselves, have been operating largely free of government regulation and oversight for decades. In 2005,

\footnotetext{
${ }^{19}$ The first Indian child to be born as a result of IVF treatments was born in 1978; by 2005, there were about 250 IVF clinics in India. INDIAN COUNCIL OF MEDICAL RESEARCH\& NATIONAL ACADEMY OF MEDICAL SCIENCES, NATIONAL GUIDELINES FOR ACCREDITATION, SUPERVISION AND REGULATION OF ART CLINICS IN INDIA (2005), 4-5 (India), http://icmr.nic.in/art/art_clinics .htm (India) [hereinafter ICMR Guidelines]. Commercially surrogacy was legalized in India in 2002. Priya Shetty, India's Unregulated Surrogacy Industry, 380 LANCET 1633, 1633 (2012). Driven by the fact that India is one of only a handful on nations that has allowed commercial surrogacy, that number ballooned to an estimated 3,000 IVF clinics by 2012. Nita Bhalla \& Mansi Thapliyal, Foreigners are Flocking to India to Rent Wombs and Grow Surrogate Babies, BUSINESS INSIDER (Sep. 30, 2013), http://www.businessinsider.com/india-surrogatemother-industry-2013-9.

${ }^{20}$ Shetty, supra note 19 at 1633 .

${ }^{21}$ Normann Witzleb \& Anurag Chawla, Surrogacy in India: Strong Demand, Weak Laws, in Surrogacy, LAW AND HUMAN RIGHTS 167, 168 (Paula Gerber \& Katie O’Byrne eds., 2015).

${ }^{22}$ Our language does not have the vocabulary to talk about surrogacy in a way that imbues a surrogate with agency and values the services she provides. Anti-commodification opponents of surrogacy use vocabulary that emphasizes a woman's body parts and suggests that she lacks choice or agency. For example, commentators refer to the services surrogates provide as renting their wombs, particularly when speaking of women in the Global South. Surrogacy industry actors have also failed to develop a more positive label for the services a woman provides. For example, American surrogacy contracts describe the payment received by the surrogate as compensation for "pain and suffering." While clearly there is pain and suffering for many women during pregnancy and childbirth, the tort law terminology does not adequately capture the role surrogates play. Intended parents are not paying to cause a surrogate "pain and suffering"- rather, they are paying for the nurturing she provides to their embryo and fetus. Thus, both actors who are opposed to surrogacy and those who favor it, have failed to develop terms that value the surrogate role in a positive way. The term "gestational care," seeks to encompass the specific type of service a surrogate provides without resorting to negative and inadequate terminology.

${ }^{23}$ In some cases, there may be a sperm donor and/or egg donor.
} 
the Indian Council of Medical Research (ICMR) issued guidelines on surrogacy, which are followed by many surrogacy clinics today, but they are neither binding nor robust. ${ }^{24}$ Since 2008, three draft bills have been proposed and have failed to pass in the Indian Parliament. While none of the prior bills banned compensated surrogacy, the most recent bill, the Surrogacy (Regulation) Bill of 2016, prohibits compensated surrogacy altogether. In November 2015, the executive had already banned transnational surrogacy by prohibiting foreigners from obtaining visas for purposes of surrogacy. Below I discuss each of these proposals and explain that a dramatic shift in regulation in 2015.

\section{$\underline{\text { ICMR Guidelines }}$}

The ICMR is a body funded by the government of India, responsible for the formulation, coordination, and promotion of biomedical research. In 2005, the ICMR, in conjunction with the National Academy of Medical Sciences published the National Guidelines for Accreditation, Supervision, and Regulation of ART Clinics in India. ${ }^{25}$ Importantly, the guidelines neither impose restrictions on who can be intended parents (both in terms of nationality and sexuality) nor do they impose restrictions on the marital status of the surrogate or the intended parents. ${ }^{26}$ The guidelines, while not binding law, remain highly influential in the medical practice.

\section{Previously Proposed Legislation in 2008, 2010, and 2014}

Prior to the most recent bill of 2016, three major draft bills have been proposed in the Indian Parliament - the Assisted Reproductive Technology (Regulation) Bill of 2008 (2008 Bill) $)^{27}$, the Assisted Reproductive Technology (Regulation) Bill of 2010 (2010 Bill), ${ }^{28}$ and the Assisted Reproductive Technology (Regulation) Bill of 2014 (2014 Bill). ${ }^{29}$ Each bill increasingly narrows who can qualify as a surrogate and as an intended parent. Both the $2008^{30}$ and the 2010 Bills $^{31}$ explicitly allowed compensated surrogacy.

\footnotetext{
${ }^{24}$ See ICMR Guidelines, supra note 19.

${ }^{25}$ Id.

${ }^{26}$ Foreign nationals and homosexual couples are not discussed whatsoever within the ICMR guidelines. The guidelines clearly contemplate that married couples would be the intending parents, but the guidelines explicitly allow single women to undergo ART treatment to have a child of her own. Moreover, the guidelines do not address the marital status of surrogate. Id. ch. 1-3. Thus, India was known to be a viable option for basically anyone; the tightening of regulations in the surrogacy industry since 2012 has led to led to a smaller surrogacy market in India and an expanding market elsewhere, such as Nepal. Danielle Preiss \& Pragati Shahi, The Dwindling Options for Surrogacy Abroad, ATLANTIC, May 31, 2016, https://www.theatlantic.com/health/archive/2016/05/dwindling-options-for-surrogacy-abroad/484688/.

27 Assisted Reproductive Technology (Regulation) Bill, 2008 (India), http://www.prsindia.org/uploads/media/vikas_doc/docs/1241500084 DraftARTBill.pdf [hereinafter 2008 Bill].

${ }^{28}$ Assisted Reproductive Technology (Regulation) Bill, 2010 (India), http://www.icmr.nic.in/guide/ART\%20REGULATION\%20Draft\%20Bill1.pdf [hereinafter $2010 \mathrm{Bill}$.

${ }^{29}$ Assisted Reproductive Technology (Regulation) Bill, 2014 (India), http://www.prsindia.org/uploads/media/draft/Draft\%20Assisted\%20Reproductive\%20Technology\%20(Reg ulation)\%20Bill,\%202014.pdf [hereinafter $2014 \mathrm{Bill}]$.

302008 Bill ch. VII, § 34(3).

312010 Bill ch. VII, § 34(3).
} 
The 2008 Bill stated that "ART shall be available to all persons including single persons, married couples, and unmarried couples," 32 and defined a couple as "persons living together and having a sexual relationship that is legal in the country/countries of which they are citizens or they are living in." 33

Under the 2008 Bill, to qualify as a surrogate, a woman must be between the ages of 21 and $45,{ }^{34}$ could not have undergone more than three surrogacies, ${ }^{35}$ and was not required to be married. ${ }^{36}$ Foreign couples were explicitly allowed to commission surrogates ${ }^{37}$ However, the 2010 Bill defined couple as two persons who cohabitate in a legal relationship in India, ${ }^{38}$ thus excluding gay Indian couples. ${ }^{39}$

The 2010 Bill, however, like the 2008 Bill, maintained that surrogacy would be available to "all persons including single persons, married couples and unmarried couples. ${ }^{40}$ The 2010 Bill did not require surrogates to be married, ${ }^{41}$ allowed foreign couples to commission surrogates, ${ }^{42}$ and restricted the age of surrogates to a range of 21 to $35 .{ }^{43}$ Finally, the 2010 Bill changed the three-surrogacies maximum to a limit of five successful live births in total, including the surrogates' own children. ${ }^{44}$

The 2014 Bill signaled a shift in surrogacy regulation towards more restriction, but still allowed commercial surrogacy. ${ }^{45}$ First, the definition of couple changed the word "persons" to "a male person and female person," 46 and defined commissioning couples as married. ${ }^{47}$ Intending couples were required to have been married for at least two years. ${ }^{48}$ Single persons were not mentioned in the 2014 Bill, excluding them as a possible intending parent. ${ }^{49}$ Moreover, a woman could become a surrogate only if she was an Indian citizen who was married and who had at least one child that was at least three years of age. ${ }^{50}$ In addition, the 2014 Bill limited surrogates to one successful birth

322008 Bill ch. VII, § 32(1).

${ }^{33} \mathrm{Id}$. ch. I, § 2(a).

${ }^{34} I d$. ch. VII, § 34(5).

${ }^{35} \mathrm{Id}$.

${ }^{36}$ Id. ch. VII, § 34(16).

${ }^{37}$ Id. ch. VII, § 34(19).

382010 Bill, ch. I, § 2(h).

${ }^{39} \mathrm{Id}$. ch. I, § 2(v).

${ }^{40} I d$. ch. VII, § 32(1).

${ }^{41}$ Id. ch. VII, § 34(16).

${ }^{42} I d$. ch. VII, § 34(19).

${ }^{43} I d$. ch. VII § 34(5).

${ }^{44} \mathrm{Id}$.

452014 Bill, ch. VII, § 60(3)(a).

${ }^{46} I d$. ch. I, § 2(p).

${ }^{47} I d$. ch. I, § 2(h).

${ }^{48} I d$. ch. VII, § 60(21)(a).

${ }^{49}$ See Id. at ch. I, ch. VII.

${ }^{50} I d$. ch. 1, § 2(zr); Id. ch. VII, § 60(5). 
through surrogacy. ${ }^{51}$ Finally, foreigners were explicitly prohibited from commissioning an Indian surrogate. ${ }^{52}$

\section{Ministry of Home Affairs Prevents Transnational Surrogacy (November 2015)}

The 2014 Bill was the first proposed legislation that sought to permit only Indians and people who qualify for the Overseas Citizenship of India to hire an Indian surrogate. ${ }^{53}$ While that bill did not pass in the Parliament, the executive, through the Ministry of Home Affairs, essentially put a halt to transnational surrogacy in November 2015 by denying foreigners medical visas for surrogacy purposes ${ }^{54}$ In January 2013, the same Ministry had already prohibited only foreign gay couples and single people from obtaining visas. ${ }^{55}$

\section{$\underline{\text { The Surrogacy Bill of } 2016}$}

The Surrogacy (Regulation) Bill of 2016 (2016 Bill), introduced on November 21, 2016, is currently pending in the Indian Parliament. ${ }^{56}$ The bill is the first proposed legislation to prohibit compensated surrogacy completely. Under the bill, any person who undertakes a surrogacy for a fee, advertises surrogacy services, or exploits a surrogate would be punished with ten years in prison and a fine ${ }^{57}$ On the other hand, uncompensated surrogacy (commonly referred to as "altruistic surrogacy"), in which the intended parents pay only for costs such as medical expenses and insurance coverage, but do not compensate the surrogate for her gestational care, would be allowed. ${ }^{58}$

Additionally, only heterosexual Indian couples, who have been married for at least five years and who are incapable of conceiving their own child, would be able to engage a surrogate. ${ }^{59}$ Even then, the surrogate would need to be a "close relative" of the intended parents, be a mother herself, be married (or have been married in the past), and have never been a surrogate before. ${ }^{60}$ The term "close relative" is not defined in the 2016 Bill, so it is unclear exactly how restrictive this limitation would be or whether it could be defined so broadly that compensation would be paid illegally to women who are not even relatives.

The 2016 Bill calls for the creation of a regulatory structure whereby state-level authorities would be responsible for verifying and granting certificates of eligibility for

${ }^{51} I d$. ch. VII, § 60(5)(a).

${ }^{52}$ Id. ch. VII, § 60(11)(a).

${ }^{53} 2014$ Bill, ch. VII, § 60(11)(a).

${ }^{54}$ Circular No. 462, supra note 17.

${ }^{55}$ Rajadhyakshal, supra note 17.

${ }^{56} 2016$ Bill.

${ }^{57}$ Id. ch. VII, § 35 .

${ }^{58}$ Id. ch. III, § 4(ii)(b); Id. ch. III, § 4(iii)(b).

${ }^{59}$ Id. ch. III, § 4(iii)(c)(II).

${ }^{60}$ Id. ch. III, § 4(iii)(b). 
anyone seeking to use surrogacy to have children. ${ }^{61}$ Thus, the 2016 Bill proposes to outlaw commercial surrogacy and to implement a rigid regulatory structure that allows uncompensated surrogacy in only narrowly defined instances. However, the standing committee of the Indian Parliament rejected key pieces of the 2016 Bill in August 2017. The standing committee called for legalization of compensated surrogacy and believe that "live-in" couples should be eligible to become intended parents (not just heterosexual married couples). However, they note that foreigners should not be allowed to commission Indian surrogates. ${ }^{62}$

The approach to surrogacy in the 2016 Bill reflects traditional notions of family in India. The ability of women to carry children using the gametes of others threatens traditional notions of family by transforming the definition of a family. Single people, gay people, and unmarried couples have the potential to have children. By prohibiting compensated surrogacy, those people are effectively prevented from having children (unless they adopt), thereby curbing the transformative effect surrogacy can have on the concept of family. Indeed, External Affairs Minister Sushma Swaraj justified the 2016 Bill in terms of values - she stated that allowing homosexual couples to avail of surrogacy simply "doesn't go with [the Indian] ethos.",63

On the other hand, having children is considered critical for a married couple in Indian society generally. ${ }^{64}$ The 2016 Bill reaffirms the family's social centrality by only allowing married, heterosexual, and childless couples to have a "close relative" carry a child for them, as long as she does not receive any money for the gestational care she provides. ${ }^{65}$ Allowing only a "close relative" to provide gestational care to another "close relative" also maintains caste purity. Finally, permitting only uncompensated surrogacy (and prohibiting compensated surrogacy) further reinforces the notion that women's work in the private sphere has no economic value. Thus, the 2016 Bill perpetuates traditional notions of family (a married man and a woman) and traditional societal values (the need for people to have children and the devaluation of women's work). ${ }^{66}$ However, the Parliamentary standing committee recognized that allowing only uncompensated surrogacy and particularly when only a "close relative" can provide gestational care can lead to abusive situations for certain women in families. ${ }^{67}$

\footnotetext{
${ }^{61} I d$. ch. III, $\S \S 4($ iii)(a)-(c).

62 Parliament of India Rajya Sabha, Department-Related Parliamentary Standing Committee on Health and Family Welfare, One Hundred Second Report on The Surrogacy (Regulation) Bill, 2016), Gazette of India Extraordinary Part II Section 2, Nov. 21, 2016, \$5.29 [hereinafter Standing Committee Report] available at https://kalantry.lawschool.cornell.edu/files/2017/08/Indian-Parliament-Report-102-1qs7ole.pdf.

${ }^{63}$ See, e.g., Cabinet approves bill to prohibit commercial surrogacy, Sushma Swaraj slams celebrities for misusing practice, THE INDIAN EXPRESS, August 25, 2016, indianexpress.com/article/india/india-newsindia/surrogacy-bill-2016-sushma-swaraj-slams-celebrities-for-misusing-practice/ [hereinafter Cabinet Approves Bill].

${ }^{64}$ See Sarojini Nadimpally, Sneha Banerjee, \& Deepa Venkatachalam, SAMA RESOURCE GROUP FOR WoMEN AND HEALTH, Commercial Surrogacy: A Contested Terrain in the Realm of Rights and Justice, in ASIAN-PACIFIC RESOURCE \& RESEARCH CENTRE FOR WOMEN THEMATIC PAPERS 9-11 (2016).

65 See 2016 Bill.

${ }^{66}$ See Nadimpally, Banerjee, \& Venkatachalam, supra note 64, at 10-11.

${ }^{67}$ Standing Committee Report supra note 62, §5.21.
} 


\section{Background on the Surrogacy SAL}

In February 2015, Jayshree Wad, a senior lawyer, upset at what she saw as the exploitation of Indian women by foreigners in media news storied, filed a SAL at the Indian Supreme Court arguing that surrogacy violates surrogates' right to "life and personal liberty." 68 Wad also argued that surrogacy has adverse health consequences on women, surrogates do not give informed consent, and that surrogates were exploited in other ways as well. ${ }^{69}$ The Supreme Court allows even individuals who are not directly impacted by the concerns they raise to bring cases directly to the Supreme Court on behalf of others whose fundamental rights under the Indian constitution have been implicated. ${ }^{70}$

This SAL on surrogacy was merged with another case on surrogacy the Court was hearing - the Jan Balaz case. The Jan Balaz case was initiated in the High Court of Gujrat and appealed to the Supreme Court in 2009. ${ }^{71}$ The controversy in that case involved a surrogate in India who had given birth to twins who were genetically related to a German couple. However, Germany prohibits surrogacy and they refused to recognize the twins as German citizens. Eventually, both governments found a solution by allowing the German couple to adopt the twins through the intercountry adoption process. $^{72}$ The Jan Balaz case was commenced in November 2009 and was resolved by May 2010. ${ }^{73}$ However, in an order dated September 4, 2014, the Court still continued the case and requested the solicitor general to opine in the next hearing about the status of a child born to an Indian surrogate. ${ }^{74}$ Then in February 2015 when the surrogacy SAL was filed, the Balaz case was merged with the surrogacy SAL. ${ }^{75}$ This allowed the Court to broaden its mandate not just to the question about the citizenship of surrogate children, but about whether or not compensated surrogacy violated the fundamental rights of surrogates.

\footnotetext{
${ }^{68}$ Petition of Jayashree Wad to Supreme Court of India (Nov. 29, 2016) (on file with author); Constitution of India, 1950 art. 21.

${ }^{69}$ See generally Sonali Kusum, Public interest litigation PIL challenging commercial, overseas, same sex, single surrogacy in India - contemporary legal judicial developments, 2 , http://www.familiesthrusurrogacy.com/wp-content/uploads/2016/05/Indian-Surrogacy-Bill-Backgroundlatest-developments.pdf.

${ }^{70}$ See S.P. Gupta v. Union of India, (1982) A.I.R. (S.C.) 149 (India). See generally Susan D. Susman, Distant Voices in the Courts of India: Transformation of Standing in Public Interest Litigation, 13 WIS. INT'L L.J. 57, 58 (1994).

${ }^{71}$ Jan Balaz v. Anand Municipality, (2010) A.I.R. (Guj.) 21 (India).

${ }^{72}$ Dhananjay Mahapatral, German surrogate twins to go home, TIMES OF INDIA, May. 27, 2010, https://timesofindia.indiatimes.com/india/German-surrogate-twins-to-go-home/articleshow/5978925.cms. ${ }^{73} \mathrm{Id}$.

${ }^{74}$ Supreme Court of India, Civil Appeal No. 8714/2010, Union of India \& Anr. V. Jan Balaz \& Ors., Item No. 105, Court No. 10, Section IX, Sept. 4, 2014, http://supremecourtofindia.nic.in/jonew/courtnic/rop/2009/35832/rop 121863.pdf.

${ }^{75}$ Hari G. Ramasubramanian, Indian Government Hurriedly Notifies Stopping of Surrogacy for Foreign Nationals, INDIAN SURROGACY LAW CENTRE (Oct. 28, 2015), http://blog.indiansurrogacylaw.com/indiangovernment-hurriedly-notifies-stopping-of-surrogacy-for-foreign-national/.
} 


\section{The Court Uses Creeping Jurisdiction in the Surrogacy SAL}

The first hearing held in the Jan Balaz case was on November $2009 .{ }^{76}$ Since then, there have been over twenty hearings in that case and then in February 2015, the surrogacy SAL was joined with the Jan Balaz case. Since the surrogacy SAL has commenced, the Court has held about twelve hearings on it. ${ }^{77}$ During the course of these hearings, the Supreme Court asked numerous government bodies, including the ICMR and the Ministry of Home Affairs, to appear to give the perspectives of those institutions on the practice of commercial surrogacy. ${ }^{78}$

In many of the hearings, the Solicitor General or another representative from the executive often deferred the questions raised by the Court by stating that they need more time to consider the issues. For example, in the hearing on October 14, 2015, the Solicitor General requests more time to consider the issues and the Court grants it. The Court notes that "the Solicitor General ... in view of the issues involved had prayed for a short adjournment, we are of the view that the Union of India should be given a large period of time to consider the matter in its entirety...",79

The Court also deferred the case when the Solicitor General advised them that a new bill on surrogacy had been proposed to the Parliament. In an order dated April 27, 2016, the Court notes that "A statement has been made on behalf of the Union of India by Shri Ranjit Kumar, learned Solicitor General for India that "The Assisted Reproductive Technology (Regulation) Bill, 2016" has been finalized for being placed before the Parliament and in all probability the said Bill would be so placed in the on-going Session of the Parliament." ${ }^{80}$ Consequently, the Court denied interim relief to the petitioner and continued the case. ${ }^{81}$

In none of its written orders does the Court actually give a firm opinion about whether or not it thinks the fundamental rights of surrogates are violated by surrogacy or any other constitutional issue. But it is clear the Court opposes surrogacy based on a set of questions it asked to the government. In an order on October 14, 2015, the Court asked the government (among other things) whether surrogacy was against the dignity of women, whether the contracts for surrogacy are against public policy, whether surrogacy

\footnotetext{
${ }^{76}$ Supreme Court of India, Petition for Special Leave to Appeal (Civil) No. 31639/2009, Union of India \& Anr. V. Jan Balaz \& Ors., Item No. 5, Court No. 11, Section IX, Nov. 25, 2009,

http://supremecourtofindia.nic.in/jonew/bosir/orderpdfold/999782.pdf.

${ }_{77}$ See Supreme Court of India, Daily Orders, http://supremecourtofindia.nic.in/daily-order (search for Civil Appeal No. 8714/2010) (last accessed January 30, 2018).

${ }^{78}$ Kusum, supra note 69Error! Bookmark not defined., at 4.

${ }^{79}$ Supreme Court of India, Civil Appeal No. 8714/2010, Union of India \& Anr. V. Jan Balaz \& Ors., Item No. 101(PH), Court No. 8, Section IX, Oct. 14, 2015, http://supremecourtofindia.nic.in/jonew/courtnic/rop/2009/35832/rop 378475.pdf.

${ }^{80}$ Supreme Court of India, Civil Appeal No. 8714/2010, Union of India \& Anr. V. Jan Balaz \& Ors., Item No. 302, Court No. 7, Section IX/PIL(W)/X, Apr. 27, 2016, http://supremecourtofindia.nic.in/jonew/courtnic/rop/2009/35832/rop 630321.pdf.

${ }^{81}$ Id. at 3.
} 
amounted to the economic and psychological exploitation of women, whether commercial surrogacy amounts to renting a womb, whether commercial surrogacy is inconsistent with the dignity of Indian womanhood, and whether commercial surrogacy involves trafficking in human beings as it involves sale of a surrogate child. ${ }^{82}$

Even when the orders were written, they did not always reflect the key points that transpired during the hearing. In one important hearing on October 14, 2015, the Supreme Court justice hearing the surrogacy SAL told officials from the central government that surrogacy should be banned. ${ }^{83}$ Specifically, the Court told the Solicitor General that

Commercial surrogacy should not be allowed, but it is going on in the country. You are allowing trading of human embryo. It is becoming a business. It has evolved into surrogacy tourism. ${ }^{84}$

These statements were reported by a print publication, the Times of India, because a reporter from the publication was probably present at the hearing. But the order that was published after the hearing on October 14, 2015 does not include these legal conclusions made by the Court that surrogacy should be banned. ${ }^{85}$ Because of the divergence of what is said orally from the bench and what is recorded in the written order, the Court's role in directing the executive to take certain policy positions go under the radar.

The surrogacy SAL is still pending and as recently as March 7, 2017, the Court heard testimony from senior counsel for the government about the status of the 2016 Bill. ${ }^{86}$ Through this creeping jurisdiction, the Court insinuates itself in a constitutional dialogue with the executive by making arguments about surrogacy based on its authority to interpret the constitution. The Court pushes the executive to ban surrogacy to rectify what it views as large-scale violations of fundamental rights. Using the constitution as a threat, the Court foreshadows how it would rule if it were judicially reviewing legislation on surrogacy, but even whilst making these threats, produces no written opinion.

\section{The Executive Responds to the Court's Directions}

\footnotetext{
${ }^{82}$ Supreme Court of India, Civil Appeal No. 8714/2010, Union of India \& Anr. V. Jan Balaz \& Ors., Item No. 101(PH), Court No. 8, Section IX, Oct. 14, 2015, http://supremecourtofindia.nic.in/jonew/courtnic/rop/2009/35832/rop_378475.pdf.

83 Amit Anand Choudhary, SC Seeks Commercial Surrogacy Ban supra note 15.

${ }^{84}$ Amit Anand Choudhary, Wary of 'tourism', SC moots ban on commercial surrogacy, TIMES OF INDIA, October 15, 2015, 2015 WLNR 30533249.

${ }^{85}$ See Supreme Court of India, Civil Appeal No. 8714/2010, Union of India \& Anr. V. Jan Balaz \& Ors., Item No. 101(PH), Court No. 8, Section IX, Oct. 14, 2015, http://supremecourtofindia.nic.in/jonew/courtnic/rop/2009/35832/rop 378475.pdf.

${ }^{86}$ Supreme Court of India, Civil Appeal No. 8714/2010, Union of India \& Anr. V. Jan Balaz \& Ors., Item No. 301, Court No. 4, Section IX/PIL(W)/X, Mar. 7, 2017, http://supremecourtofindia.nic.in/jonew/bosir/orderpdf/2872643.pdf.
} 
After the hearing on October 14, 2015, where the Court stated that it thought surrogacy commodified human life, the Ministry of Home Affairs issued a notice that effectively banned transnational surrogacy by refusing to grant visas to foreigners for purposes of surrogacy in November 2015..$^{87}$

While there is no direct evidence linking the two, the timing of the ban by the ministry and the hearings of the Supreme Court suggest that the decision to ban international surrogacy is related to pressure by the Court. ${ }^{88}$ In fact, some saw the government's adoption of a total ban on transnational surrogacy as a way to avoid answering the difficult questions the Supreme Court had posed regarding the rights of various parties in surrogacy arrangements. ${ }^{89}$ It is also possible that the government was already considering banning foreigners from engaging in surrogacy in India and the timing of the Supreme Court hearings were just coincidental, or simply expedited the process that was already underway.

Indeed, the Court's stance against compensated surrogacy clearly found sympathetic ears in the executive. The Hindu nationalist party, the Bharatiya Janata Party (BJP), rose to national power in 2014. The prohibition on foreigners obtaining visas for surrogacy purposes was adopted in November 2015 after the BJP gained power and also after the surrogacy SAL was filed. The Court notes in an order dated October 28, 2015 that the solicitor general, Mr. Ranjit Kumar, "has submitted that certain decisions have been taken by the Union of India pursuant to the last order of this Court dated 14th October, 2015."90 The representation of the Solicitor General to the Court suggests that the Court's views from the bench that it opposed the practice of surrogacy on constitutional and moral grounds seem to have influenced the government's forthcoming ban on transnational surrogacy.

Then one year after the surrogacy SAL, the BJP sought to ban compensated surrogacy even for Indian intended parents in the 2016 Bill. ${ }^{91}$ As mentioned above, the

\footnotetext{
${ }^{87}$ Circular No. 462 supra note 17.

${ }^{88}$ Ramasubramanian, supra note 75.

${ }^{89}$ See Id.; Dhananjay Mahapatral, SC notice to govt on SAL seeking ban on commercial surrogacy, TIMES OF INDIA, Feb. 26, 2015, http://timesofindia.indiatimes.com/india/SC-notice-to-govt-on-SAL-seeking-banon-commercial-surrogacy/articleshow/46376012.cms. In a recent article, Amrita Pande also suggests that the turn towards banning surrogacy was because of the Supreme Court and several high profile cases. "Transnational Commercial Surrogacy in India: to ban or not to ban," in Babies for Sale: Transnational Surrogacy, Human Rights and The Politics of Reproduction (editor Miranda Davies), Zed Books London, 2017, p. 330 (citing Supreme Court asks Centre to bring commercial surrogacy within ambit of law, THE INDIAN EXPRESS, Oct. 15, 2015, http://indianexpress.com/article/india/india-news-india/supreme-courtasks-centre-to-bring-commercial-surrogacy-within-ambit-of-law/)

${ }^{90}$ Supreme Court of India, Civil Appeal No. 8714/2010, Union of India \& Anr. V. Jan Balaz \& Ors., Item No. 101(PH), Court No. 8, Section IX, Oct. 28, 2015, http://supremecourtofindia.nic.in/jonew/courtnic/rop/2009/35832/rop_383488.pdf.

${ }^{91}$ Surrogacy (Regulation) Bill, No. 257 of 2016 (India), available at http://164.100.47.4/BillsTexts/LSBillTexts/Asintroduced/257_LS_2016_Eng.pdf [hereinafter 2016 Bill]; see Cabinet approves bill to prohibit commercial surrogacy, Sushma Swaraj slams celebrities for misusing practice, THE INDIAN EXPRESS, August 25, 2016, indianexpress.com/article/india/india-news-
} 
2016 Bill was a complete reversal of prior policy. Each prior bill would have permitted compensated surrogacy, but the 2016 Bill, which was proposed by the executive after the surrogacy SAL was initiated, was the first time the executive sought to ban surrogacy. However, it should be noted that the surrogacy ban on foreign gay people and single individuals was adopted in 2013 and precedes the BJP and the surrogacy SAL. ${ }^{92}$

The Court's constitutional threats may have had no impact on a new turn towards prohibition of surrogacy because the BJP government may have proposed a bill banning compensated surrogacy even without the Court's interventions. However, given the timing of the surrogacy SAL hearings and the prohibitionist stance as reflected in the visa ban for foreigners for surrogacy purposes and the 2016 Bill, the Court's constitutional threats could have certainly played a role in pushing for a policy change or at least expediting it.

\section{The Surrogacy SAL Reveals the Shortcomings in Modern SAL}

Professor Baxi rightly valorized SAL in its early days. ${ }^{93}$ SAL was intended to address violations of fundamental rights of marginalized groups. In S.P. Gupta v. President of India, Justice Bhagwati noted that the goal of developing SAL was to promote "easy accessibility to justice" and ensure that "large masses of people belonging to the deprived and exploited sections of humanity may be able to realise and enjoy the socio-economic rights granted to them." 94 The Court gained a voice through SAL that it previously lacked in India's democratic system. In many cases, it successfully monitored and rectified violations of fundamental rights perpetrated by the state and actors under the control of the state. Other legal scholars have also largely valorized SAL and when they critique it, it is to lament that the Court has taken fewer SAL cases in the 1990s than it did in the 1980s. ${ }^{95}$

More recently, however, even legal scholars have begun to critique SAL. Professor Bhuwania recently made a larger structural critique of SAL. ${ }^{96}$ Among other things, he argues that sometimes when hearing SAL cases, the Supreme Court and the High Courts marginalize petitioners' views and do not obtain the views of parties that will be impacted by the litigation. ${ }^{97}$

The reason for the growing critique of SAL from the left may be because the SAL cases that are being brought before and admitted by the Supreme Court are not as clear

\footnotetext{
india/surrogacy-bill-2016-sushma-swaraj-slams-celebrities-for-misusing-practice/ [hereinafter Cabinet Approves Bill].

${ }_{92}$ See Circular No. 462, supra note 17.

${ }^{93}$ See Baxi, Taking Suffering Seriously, supra note 4.

${ }^{94}$ See S.P. Gupta v. Union of India, (1982) A.I.R. (S.C.) 149, 157 (India).

${ }^{95}$ See, e.g., Shylashri Shankar, SCALING JusticE: INDIA's SuPREME COURT, ANTI-TERROR LAWS, AND SOCIAL RIGHTS (2009).

${ }^{96}$ Anuj Bhuwania, Courting the People: Public Interest Litigation IN Post-EMERgency India (2017).

${ }^{97} I d$. at $11,39-44$.
} 
cut as the cases described by Baxi in his article Taking Suffering Seriously. The surrogacy SAL is an example of such a case - unlike the SAL cases described by Professor Baxi, the surrogacy SAL does not involve the government as the perpetrator of the harm nor is it clear what exactly the government should do to stop the harm. ${ }^{98}$

Despite the differences between traditional SAL cases and the surrogacy SAL, the presiding judge in the surrogacy SAL continued to use the traditional techniques used in SAL cases - namely, creeping jurisdiction. The Court kept jurisdiction over the case since 2009 and held dozens of hearings over the course of time. The case is still open to date. It questioned and pushed government officials to prohibit compensated surrogacy. Below I describe three concerns with the use of creeping jurisdiction in the surrogacy SAL.

First, by holding numerous short hearings where it pushes the executive towards one normative policy position instead of issuing a final opinion, there is a risk that the Court will formulate its opinions without ever hearing from all of the parties impacted in the case and considering the issues from all sides. Indeed, in the surrogacy SAL, the Court pushed the executive to ban compensated surrogacy without giving an opportunity to surrogates to intervene when the surrogates sought to argue that surrogacy provides them with much needed work opportunities and livelihood.

Instead, when surrogates approached the Supreme Court asking to intervene in the surrogacy SAL, they were not allowed. ${ }^{99}$ Surrogates who attempted to intervene argued that the ban denied them a right to livelihood and reproductive autonomy, discriminated against foreigners, and prevented the creation of families. ${ }^{100}$ According to an advocate present in the Court during the hearing where the surrogates' motion to intervene was heard, the Court deferred their intervention on the basis that the executive was already drafting a policy and law. ${ }^{101}$ Professor Anuj Bhuwania provides other examples of cases where the voices of the impacted parties were not heard by the Court in SAL cases. ${ }^{102}$

There is little scholarly work that investigates the opinions of surrogates in regard to surrogacy. Most of the scholarly work on Indian surrogates consists of sensitive and

\footnotetext{
${ }^{98}$ It is interesting to note that there are similarities between the surrogacy SAL and the SAL cases of the 1980s that Professor Baxi describes is that the surrogacy SAL was initiated by a concerned citizen who was not at all personally impacted by issue and her petition was based solely on media reports. Petition of Jayashree Wad to Supreme Court of India (Nov. 29, 2016) (on file with author). Advocate Radhika Thapar also notes that the petitioner presented "very few incidents of exploitation, projected through various media and magazine reports." Rajni Pandey, 'Restriction on surrogacy may have far reaching impact', INDIA MEDICAL TIMES, October 20, 2015, www.indiamedicaltimes.com/2015/10/20/restriction-on-surrogacymay-have-far-reaching-impact/.

${ }^{99}$ Prabhati Nayak Mishra, Surrogate Mothers Seek Supreme Court's intervention, DAILY NeWS AND ANALYSIS INDIA, Nov. 26, 2015, http://www.dnaindia.com/india/report-surrogate-mothers-seek-supremecourt-s-intervention-2149015.

${ }^{100} \mathrm{Id}$.

101 Phone interview with Advocate Radhika Thapar, December 8, 2017.

102 Bhuwania, supra note 96, at 11.
} 
illuminating ethnographies by anthropologists. ${ }^{103}$ To better understand the surrogates' perspective on whether compensated surrogacy should be legal, eight Cornell Law students, Professor Bradley Wendel, and I interviewed surrogates in India. We worked in collaboration with Professors Aparna Chandra and Mrinal Satish and eight students at the National Law University in Delhi as part of a semester-long global classroom. ${ }^{104}$ When asked about it, the surrogates we spoke with said they wanted the right to sell gestational care.

As part of the fieldwork, teams of four students visited medical clinics and interviewed doctors and surrogates, and also visited surrogacy homes. Surrogacy homes are places where surrogates live especially during the late term of their pregnancies. The homes are run by medical professionals or their agents. In total, we conducted nine semistructured interviews of surrogates in New Delhi and Anand, Gujarat, and each interview lasted approximately one hour. It should be noted that the surrogates we spoke to were referred to us by fertility and surrogacy medical professionals, and some interviews took place in surrogacy homes. Thus, there is likely sample bias. Nor are the interviews representative of all surrogates.

Although in the interviews the surrogates voiced many concerns about their living conditions and legal issues, all the surrogates we interviewed, including surrogates in their second surrogate pregnancy, thought surrogacy should be legal. The surrogates believed that the law should permit them to continue on their chosen path, noting that being a surrogate enabled them to earn money that would both support their families and help others become parents at the same time.

One woman told us, for example, "I want to do it again, not one but even ten times. I do not think there are any issues and I want to get more people to do it. Without

${ }^{103}$ See, e.g., Amrita Pande, "At Least I Am Not Sleeping with Anyone": Resisting the Stigma of Commercial Surrogacy in India, 36:2 FEMINIST STUD. 292 (2010), claradoc.gpa.free.fr/doc/420.pdf; Amrita Pande, Commercial Surrogacy in India: Manufacturing a Perfect Mother-Worker, 35:4 Signs 969 (Summer 2010); Sheela Saravanan, Transnational Surrogacy and Objectification of Gestational Mothers, 45:16 ECON. AND POLITICAL WeEKLy April 17, 2010; Daisy Deomampo, Transnational Surrogacy in India: Interrogating Power and Women's Agency, 34:3 Frontiers: J. WOMEN STUD., SPECIAL ISSUE: REPROD. TECH. AND REPROD. JUST. 167 (2013).

${ }^{104}$ CORNELl LAW SCHOOL, In "Global Classroom," Students Study Surrogacy Law and Policy in India and the United States, May 1, 2017, http://www.lawschool.cornell.edu/spotlights/In-Global-ClassroomStudents-Study-Surrogacy-Law-and-Policy-in-India-and-the-United-States.cfm. My Indian co-professors, Professors Chandra and Satish, submitted a memo of the students' preliminary research findings to the standing committee in parliament that is currently reviewing the Surrogacy Bill of 2016, and we are currently working to produce a report synthesizing our desk research and fieldwork with the goal of providing relevant information to the Indian Parliament as it deliberates the bill. Clinical students also interviewed compensated surrogacy stakeholders in the United States and will produce a legislative policy report on the Child-Parent Security Act, a bill legalizing compensated surrogacy, which is in a committee in the New York legislature. Child-Parent Security Act Bill of 2016, Assemb. B. 4319, 2015 Assemb., Reg. Sess. (N.Y. 2016). The interviews cited here were conducted by students supervised by an instructor and other students took notes at the interview and all interviewees review and revised the notes after the interview. 
money there is no life." 105 Another surrogate told us, "The thought of giving a child to someone else is incomparable, there is nothing else that makes me so happy. I also wanted to make money for my child's future. . . I did not consider it to be bad. You get to give someone a child and the government should not ban this. I want there to be children in all houses. ... [The proposed surrogacy ban] is not good. Some people have so much money but no children. There is nothing better than what we are doing." 106

Yet another surrogate we interviewed told us, "Surrogacy should not be banned. The ban will hurt poor people, will take away opportunity from them. Surrogacy is a winwin situation for both the parties. We get blessings and money from them and they get their own child. This is good work. It is preferable to other jobs that would be available to us." ${ }^{107}$ One of the surrogates we interviewed noted that although she did not think surrogacy should be banned, she did think the government had a role to play in making sure that the process works. ${ }^{108}$

Our interviews with surrogates clearly demonstrate that surrogates have valuable opinions to add to the debate. Most often, and perhaps expectedly, surrogates are supportive of the practice in general. They cite the economic benefits surrogacy brings to them and their families, but they also value the intangible social contribution of giving a child to a childless family. Moreover, the surrogates we interviewed recognized that government regulation is necessary, to an extent, to give physical and economic safety to the surrogates. Thus, when surrogates are consulted, they uniformly believe that they should have the right to provide gestational care under the umbrella of government protections.

It may just be that the modern Supreme Court is much more overburdened than the Court of the 1980s. ${ }^{109}$ Many more petitions are filed today than decades ago and it admits more cases. Its capacity to engage in broad-reaching fact-finding and due diligence is more limited than it was before. On the other hand, on the question of surrogacy, the standing committee of the Rajya Sabha did take the time to engage more broadly with all stakeholders on the issue and produced an 88-page report in August 2017 evaluating the 2016 Bill that was proposed by the executive to Parliament. ${ }^{110}$

The Parliamentary Standing Committee rejected the executive's proposal to ban compensated surrogacy, and instead found that "preventing [surrogates] from being paid for their reproductive labour is grossly unfair and arbitrary." 111 They sent a clear rejection to the executive of its policy. The standing committee's deliberations over the bill were

\footnotetext{
105 Interview with Sharda and Meera, Anand, Gujarat (Apr. 3, 2017).

106 Interview with Shanta and Kanta, Anand, Gujarat (Apr. 7, 2017).

${ }^{107}$ Interview with Amita and Sona, Anand, Gujarat (Apr. 7, 2017).

${ }^{108}$ Interview with Anonymous, Gupta Clinic, New Delhi, India (Apr. 5, 2017).

${ }^{109}$ In 1980, 21,749 cases were admitted to the Supreme Court. This number had more than tripled to 71,460 by 2016. Supreme Court of India Annual Report 2016-2017, 58-59, supremecourtofindia.nic.in/pdf/AnnualReports/Annual\%20Report\%202016-17.pdf.

${ }^{110}$ See One Hundred Second Report on The Surrogacy (Regulation) Bill, 2016, supra note 67.

${ }^{111}$ Id. at $\$ 5.18$.
} 
far more robust than the Supreme Court's deliberations. It heard testimony from the Ministry of Women and Child Development, the National Commission of Women, the Ministry of Home Affairs, the Ministry of External Affairs, the Federation of Obstetric and Gynecological Societies of India, the Indian Society of Third Party Assisted Reproduction, the International Surrogacy Forum, the National Advisory Committee for Drafting of Guidelines on Assisted Reproductive Technology, lawyers, including Jayshree Wad, and other lawyers associated with Indian NGOs dealing with surrogacy, a journalist and human rights activist, a law student, a professor of Indian constitutional law, surrogate mothers, and a parent who had commissioned surrogacy. ${ }^{112}$ The Cornell International Human Rights Clinic and the Transnational Seminar at the National Law University in Delhi also submitted a memo to the standing committee. ${ }^{113}$ Professor Satish testified before members of the standing committee on July 4, 2017.

While the Supreme Court held many hearings in the case, they were short and they never heard the views of the very people whose fundamental rights were claimed to be violated even when those parties attempted to intervene. The Court may be able to come to a better resolution of the issues through robust fact-finding inquiries and meaningful participation of all stakeholders. Yet, given its modern workload, it may no longer have the capacity to undertake this task in many SAL cases. Thus, the normative view that the Court advances with executive failed in the surrogacy SAL to reflect the complexities of the situation.

Second, when using creeping jurisdiction, the Court does not need to issue a final written judgment. By failing to issue a final written judgment the Court abdicates responsibility to engage with prior precedents and develop constitutional and legal arguments on both sides of the issues. But if it were to invest the time in writing a legal opinion, the normative view that it developed would be much more reasoned than the view it puts forward in its creeping jurisdiction.

Third, when the Court does not issue a final order, but instead issues numerous interim orders, many of which are issued orally, but not documented, its role in pushing for policy changes often goes under the radar. This insulates the Court from critique and accountability for its role in executive and legislative decision-making. Certainly, the Court is not like the Parliament whose members are elected and subject to re-election. It is essential for voters to be aware of how members of Parliament vote and the stance they take on various issues in order to evaluate their re-election. Even though the Court is not and should not be swayed by public opinion, it is still important for its actions to be transparent. When the Indian Supreme Court issues oral orders in creeping jurisdiction cases rather than a final opinion, the public is not even aware of the important role the Supreme Court has played in shaping policy as there are no written orders or opinions, and therefore does not have any opportunity to react to the Supreme Court's directions.

\footnotetext{
112 Id. at $\$ 4.1-16$.

${ }^{113}$ National Law University, Delhi and Cornell Law School, Memorandum on The Surrogacy (Regulation) Bill 2016, https://kalantry.lawschool.cornell.edu/files/2017/08/CLPG-NLU-Delhi-Cornell-Memorandumon-Surrogacy-Bill-2016-1s985d1.pdf.
} 


\section{Legal Solutions to 'Exploitation' of Surrogates}

The petition in the surrogacy SAL argues that poor women who become surrogates are exploited and face abusive situations. By pushing the government to ban surrogacy, the Court is doing what it thinks will help women in India who act as surrogates. However, I propose an alternative solution to protect surrogates rather than a knee-jerk ban on surrogacy. Below I argue that word "exploitation" which is often used to describe the plight of surrogates needs to be disaggregated. ${ }^{114}$ When disaggregated, we see that the type of exploitation that occurs in practice because of the unequal bargaining power between the parties to the surrogacy contract is something that can be addressed by government legislation.

First, when Marxists argue that surrogates are exploited by foreigners or rich Indians, they mean that the purchase and sale of gestational care is inherently exploitative to the person who sells it. ${ }^{115}$ For example, a blog post on the website of the All India Democratic Women's Association (AIDWA), the women's wing of the communist party, states that that the growth of the surrogacy industry "signifies the crassest form of commodification of the female body as well as the alienation that capitalism represents." 116

Marxists and other critics of global capitalism argue that an Indian surrogate is exploited by pointing out that she makes significantly less money than a surrogate in the United States. While the market rate for gestational care in India is approximately $\$ 5,000,{ }^{117}$ it ranges between $\$ 25,000$ and $\$ 40,000$ in the United States. ${ }^{118}$ However, when examined within their own contexts, it appears that the Indian surrogate makes much more relative to her household income. An Indian surrogate typically gets six times her annual household income for one surrogate pregnancy, ${ }^{119}$ whereas American surrogates are typically middle-class women whose income from surrogacy is often less than their annual household income. ${ }^{120}$ Even if the Marxists' economic argument can be disproved,

\footnotetext{
114 John Lawrence Hill, Exploitation, 79 CORNELL L. REV. 631, 637-644 (1994).

${ }^{115} \mathrm{Id}$. at 632 .

${ }^{116}$ Indu Agnihotri, Commercial Surrogacy and Assisted Reproductive Technologies: Some Issues, ALL INDIA DEMOCRATIC WOMEN's ASS'N, Oct. 20, 2008, http://aidwaonline.org/post/commercial-surrogacyand-assistedreproductive-technologies-some-issues; see also Mohan Rao, Why All Non-Altruistic Surrogacy Should Be Banned, ECON. \& POL. WKLY., May 26, 2012.

117 Centre for Social ReSEARCH, Report on the National Conference on Surrogacy: “A Policy Dialogue on Issues around Surrogacy in India," 14, Sep. 2014, https://drive.google.com/file/d/0Bf1XIdg1JC_ZmlsZXQwY3VvcW8/view [hereinafter CSR: Report on Conference]; CENTRE FOR SOCIAL RESEARCH, Surrogate Motherhood - Ethical or Commercial, 41 (2010), https://drive.google.com/file/d/0Bf1XIdg1JC_UGh5UTNxUGxMV1k/view [hereinafter CSR: Surrogate Motherhood].

${ }^{118}$ Mark Bowerman \& Ashley May, Myths about IVF, surrogacy and adoption, U.S.A TODAY, Apr. 22, 2017, https:/www.usatoday.com/story/news/nation-now/2017/04/22/myths-ivf-surrogacy-andadoption/100331024/.

119 Julie Bindel, Outsourcing Pregnancy: a visit to India's surrogacy clinics, GUARDIAN, Apr. 1, 2016, https://www.theguardian.com/global-development/2016/apr/01/outsourcing-pregnancy-india-surrogacyclinics-julie-bindel.

${ }^{120}$ According the U.S. Census Bureau, in 2015 the median income of a full-time, year-round working woman was \$40,742. U.S. Census Bureau, Current Population Survey, 1961 to 2016 Annual Social and
} 
the moral or philosophical position will still remain unchanged - that laborers (including reproductive laborers) are inherently exploited in a capitalist system. ${ }^{121}$ For them capitalism is problematic generally and buying and selling gestational care represents the crassest form of it. ${ }^{122}$ For Marxists and others who take the commodification view of surrogates, even if surrogates received fair terms, surrogacy should still be banned.

A second variant of "exploitation" is akin to the contract law concept of "duress." For example, one senior health official noted that the purpose of restrictive legislation is "to prevent exploitation of Indian women who may be tempted to take the risk of surrogacy in the face of financial hardships." ${ }^{123}$ Here, the health official is referring to the temptation to take an offer to make a significant amount of money given a person's financial circumstances, a temptation which would not exist without a surrogate's poverty. The problem with this argument is that women who act as surrogates in India are likely already making choices based on their financial hardships. Many poor women in India toil as underpaid domestic laborers or on dangerous construction sites. Were it not for their financial needs, they would likely not engage in those labor-intensive and underpaid jobs either. There are, however, no calls to ban domestic labor or construction work for women.

A third way in which people use "exploitation" is to mean the lack of informed consent. SAMA Resource Group for Women and Health, for example, objects to the medical procedures involved in both surrogacy and infertility procedures. They are concerned that the medications used for in vitro fertilization (IVF) by both the intended mother/egg donor and the surrogate are harmful to women, and that the information about potential side effects is not provided and may not yet be known. ${ }^{124}$ Pinki Virani, author of Politics of the Womb: The Perils of IVF, Surrogacy and Modified Babies, approaches the topic from a similar angle. ${ }^{125}$ It may be possible to address these concerns if the government enacts regulation to attempt to ensure that surrogates obtain accurate and more detailed information about the medications they will be required to take and the procedures they will undergo.

A fourth understanding of exploitation focuses on unfair terms that surrogates receive because of the inequities in the bargaining process. The medical professionals are from wealthy classes in society; in relation to the surrogates they have both more social

Economic Supplements, https://www2.census.gov/programssurveys/demo/visualizations/p60/256/figure2.pdf. The median income for a family household, between 2014 and 2015, was \$68,504. U.S. CENSus BuREAU, Current Population Survey, 2015 and 2016 Annual Social and Economic Supplements, https://www.census.gov/library/publications/2016/demo/p60-256.html.

${ }^{121}$ Hill, supra note 114 , at 632, 680-82.

${ }^{122}$ Mohan Rao, Why All Non-Altruistic Surrogacy Should Be Banned, 47:21 Econ. \& Political Weekly, May 26, 2012.

${ }^{123}$ Bindu Shajan Perappadan, Surrogate mothers appeal to ICMR, seek 'dignity, ' HINDU, Nov. 6, 2015, http://www.thehindu.com/news/national/other-states/surrogate-mothers-appeal-to-icmr-seekdignity/article7848219.ece.

${ }^{124}$ See Nadimpally, Banerjee, \& Venkatachalam, supra note 64, at 6.

125 Pinki Virani, Politics OF THE WoMB: The PerILS OF IVF, SURRoGACY AND ModifiEd BABIES (2016). 
power and more knowledge about the medical process. The surrogates are most often women who do not speak English, live in slums, and are squatters. ${ }^{126}$ Exploitation is possible when there is such great income, educational and social inequalities between the bargaining parties. ${ }^{127}$ Intended parents also enter into contracts with surrogates, but their relationship is more distant from the surrogate than the medical professionals (although of course similar inequalities exist between intended parents and surrogates as well).

Indeed, without any government regulations surrogates are left to negotiate or more likely just accept whatever terms are given to them. ${ }^{128}$ Our interviews with surrogates suggest that the private contract model fails to protect surrogates in India. There are both substantive and procedural problems in the contracting process. One surrogate we interviewed told us that she was not sure if she would receive any compensation if the pregnancy had a negative outcome. ${ }^{129}$ Her friend, another surrogate, noted that "[surrogates] do not ask such questions." 130 Another surrogate we interviewed was unsure about the actual amount she was to receive, whether she was receiving any monthly payments, and how she would receive payment. ${ }^{131}$ The women also did not have a say in how they would deliver the babies they were carrying, and the women told us that the prevailing method of delivering the surrogates' babies was through Caesarean sections. ${ }^{132}$ Relatedly, one of the women we spoke with had been informed that the commissioning parents would not pay any additional amount to reimburse her for any post-operation expenses, even though she would be unable to return to work to earn an income. ${ }^{133}$ Another interview revealed that women were responsible for any post-delivery medical issues and expenses that might arise. ${ }^{134}$ All of this suggests that the surrogates do not understand the key terms and repercussions of their own surrogacy contracts (if they have contracts at all).

Indeed, one of the surrogates we spoke with told us that her contract had been in English, not in Hindi, and that she could not read it, though she signed it after her husband read it. ${ }^{135}$ The women also noted that the agent physically held all of the contracts and the women did not have their own copies. ${ }^{136}$ Indeed, one of the agents we interviewed showed us a contract that stated explicitly that the surrogate would not be allowed to keep a copy of the contract. ${ }^{137}$ The surrogates and agents also told us that the

\footnotetext{
126 See CSR: Report on Conference, supra note 117, at 14.

127 See Hill, supra note 114, at 634.

${ }^{128}$ Elsewhere I discuss why the private contract law model serves to create surrogate-protective norms, while the Indian legal system does not create such norms. Sital Kalantry, Regulating Markets for

Gestational Care: Comparative Perspectives on Surrogacy in the United States and India, CoRNELL J.L. \& PUB. POL'Y (forthcoming).

${ }^{129}$ Interview with Sharda and Meera, supra note 105.

${ }^{130} I d$.

${ }^{131}$ Interview with Maithili Devi, New Delhi (Apr. 5, 2017).

132 Interview with Sharda and Meera, supra note 105; interview with Shanta and Kanta, supra note 106.

${ }^{133}$ Interview with Sharda and Meera, supra note 105.

${ }^{134}$ Interview with Amita and Sona, New Delhi, India (Apr. 5, 2017).

${ }^{135} \mathrm{Id}$.

${ }^{136}$ Interview with Sharda and Meera, supra note 105.

${ }^{137}$ Interview with agent, Surrogacy Home, Gurgaon, India (Apr. 5, 2017).
} 
contracts signed by the surrogates were not reviewed by anyone providing legal counsel to the surrogates. ${ }^{138}$

Other studies also demonstrate that many surrogates in India are not treated fairly. A Centre for Social Research survey of one hundred surrogates finds that the majority of surrogates underwent embryo transfer prior to signing a contract and was only promised payment for a successful pregnancy. ${ }^{139}$ The surrogates bear all the financial and health risks associated with the medical procedures. ${ }^{140}$ Surrogates also bear the risk of miscarriages and receive no compensation for the medical procedures they underwent prior to the miscarriage. ${ }^{141}$ Finally, only about ten percent of the contracts reviewed by the Centre for Social Research discussed compensation at all, and almost none of the contracts addressed whether there would be any provision of medical care after the birth of the child. ${ }^{142}$

In many cases the surrogacy process goes as planned - the embryo transfer successfully leads to a pregnancy, the surrogate gives birth, the surrogate receives her compensation and does not face adverse health consequences. The medical professionals are, in some cases, benevolent. They provide post-natal care even when they are not legally obligated to do so. Some doctors even view their work as a tool to further social justice, and some provide educational classes to surrogates that go beyond what is required by contract. ${ }^{143}$ But, even in cases where everything goes as planned, the allocation of risk clearly reveals the failures in the bargaining process.

To address the exploitation that occurs in the vast inequality of bargaining power between the surrogates, on the one hand, and doctors and intended parents, on the other hand, the government should adopt requirements that require the medical professionals and/or intended parents to provide certain rights to surrogates. For example, the regulations could specify that surrogate should be compensated for undergoing the embryo transfer even if she miscarries, that there should be limitations on the number of embryos transferred, that she should be provided with post-natal care, that intended parents pay for legal representation for the surrogates, and that she receive life and health insurance.

Some suggestions for regulating consumer contracts in the United States could be relevant to the surrogacy industry in India. In many countries, consumers are forced to sign long, boilerplate contracts, in which they waive numerous rights in exchange for receiving certain services or goods from large businesses. Consumers have no ability to

\footnotetext{
${ }^{138}$ Interview with Sharda and Meera, supra note 105.

${ }^{139}$ CSR: Surrogate Motherhood, supra note 117, at 41, 58-60.

140 See Id. at 63-66.

${ }^{141}$ See Id. at 63.

${ }^{142}$ Id. at 65.

143 AKanksha Hospital \& Resarch Center, Dr. Nayana H. Patel, http://ivfsurrogate.com/DrNayanaPatel.
} 
negotiate terms of the contract. ${ }^{144}$ Everyone knows that most consumers sign boilerplate contracts without reading them, but American courts generally bind consumers to those terms anyway. ${ }^{145}$ In the Indian context, there are many similarities between surrogacy contracts and consumer contracts. There is great inequality in bargaining power between the parties: many surrogates do not read or understand their contracts, they have no legal representation, and they are given form contracts with little ability to negotiate any terms.

Scholars have proposed several ways to rectify the problems in the consumer context. First, Professors Hillman and O'Rourke suggest increased disclosure as a way to address the problems they see with consumer contracts. ${ }^{146}$ In regulating surrogacy contracts, jurisdictions could require that the potential adverse consequences of the medications and medical procedures surrogates will undergo be disclosed in writing in the contract or published widely so that they may be reviewed by advocacy groups.

A second approach involves creating a list of presumptively unenforceable terms. The European Union has adopted this approach in their Directive on Unfair Terms, which creates a non-exhaustive list of unenforceable terms in consumer contract. ${ }^{147}$ A similar list could be useful in the surrogacy contract context to prevent unfair terms against surrogates. One such term that could be invalidated by law is a provision that prevents a surrogate from terminating the pregnancy. ${ }^{148}$

A third approach to consumer protection advocated by Professor Margaret Radin suggests that governments require that contracts include certain provisions. ${ }^{149}$ Some jurisdictions already have adopted mandatory rules in surrogacy contracts. For example, a leading surrogacy destination, the state of California in the United States, requires that a contract contains the means to cover the surrogate's financial expenses, either by the intended parents or the surrogate's own health insurance. ${ }^{150}$ The state of Delaware further requires that consideration must be "reasonable" and that funds must be placed in escrow before an embryo transfer occurs. ${ }^{151}$ Along the lines of mandatory rules, one author

\footnotetext{
${ }^{144}$ See Ian Ayres \& Alan Schwartz, The No-Reading Problem in Consumer Contract Law, 66 STAN. L. REV. 545, 545-46 (2014).

145 Id. at 548-49.

${ }^{146}$ Robert A. Hillman \& Maureen O’Rourke, Defending Disclosure in Software Licensing, 78 U. CHI. L. REV. 95, 103-04 (2011).

${ }^{147}$ Council Directive 93/13, art. 3(3) Annex, 1993 O.J. (L 95) 29 (EU).

148 The bill to legalize surrogacy in New York state contains such a provision. Child-Parent Security Act, A-6959A, 2017-2018 Reg. Sess. § 581-401 (N.Y. 2017).

${ }^{149}$ Margaret Jane Radin, BoILERPLATE: ThE FINE PRINT, VANISHING RIGHTS AND THE RULE OF LAW 213 (2013) (" $[\mathrm{M}] \mathrm{y}$ preliminary suggestion is that a purported contract containing offending boilerplate should be declared invalid in toto, and recipients should instead be governed by the background legal default rules").

${ }^{150}$ CAL. FAM. CODE $§ 7962$ (a)(4) (West 2018) (the statute also requires that the contract contain: (i) the date on which the assisted reproduction agreement for gestational carriers was executed; (ii) the persons from which the gametes originated, unless donated gametes were used; and (iii) the identity of the intended parent or parents).

15179 Del. Laws tit. 13, ch. $8 \S 8-807(d)(3)$ (2013) ("The agreement of the intended parent or parents to pay the gestational carrier reasonable compensation").
} 
suggests that, like in an adoption setting where parents have the right to change their minds, surrogates should have the unilateral right to terminate the contract within a limited window of time and keep the baby. ${ }^{152}$ Another possible mandatory rule a jurisdiction could enact is to require intended parents pay for independent legal representation for a surrogate.

A fourth approach would be to require pre-approval of individual contracts. Israel has adopted this method for surrogacy contracts. ${ }^{153}$ A fifth approach, like that of the American Consumer Protection Bureau, is to create an agency that takes consumer complaints and promulgates regulations to enhance consumer protections.

Another approach to regulating surrogacy contracts is a labor law model. ${ }^{154}$ Indeed, surrogacy contracts are similar to employment contracts. In surrogacy contracts, like employment contracts, the vulnerable party is typically the provider of services and the one in need of protection. As Professor Cyra Choudhury observed, "the state can intervene to equalize some of the bargaining disparities . . through worker rights and mandatory contractual requirements." ${ }^{155}$ A labor model is also useful because it allows jurisdictions to regulate industry actors that would otherwise not be covered by contractlaw regulations. Regulating only the contractual relationship (which exists between the surrogate and the intended parents) will not hold matching entities and fertility specialists accountable. Jurisdictions should consider enacting regulations to directly address their behavior to ensure that they act in ways that are fair to surrogates.

In sum, the types of regulations used to address inequities in consumer contracts and labor regulatory models can both be useful tools to mitigate the abuses surrogates face in in India. This is an alternative that protects a surrogate from exploitation in the sense of laboring under unsafe and risky conditions, but at the same time allows her to earn much-needed resources for her family.

Those familiar with law and policy in India may respond to my proposal by saying that even if India were to adopt state-of-the art legislation to protect all the vulnerable parties in a surrogacy arrangement, surrogacy law would be flouted just like many other laws in India. But just because law is sometimes not followed in India does not mean that appropriate laws should not be crafted or adopted. In addition, in many cases laws geared towards ensuring women's equality in India (e.g., anti-dowry laws) attempt to regulate private behavior, which is difficult to enforce. On the other hand, laws regulating surrogacy involve more public transactions between medical professionals, intended parents, and an unrelated third party (the surrogacy). This makes it more difficult to hide than other medical transactions (such as sex determination). Finally, surrogacy industry actors would be motivated to comply with legislation that regulates

\footnotetext{
${ }^{152}$ David M. Smolin, Surrogacy as the Sale of Children: Applying Lessons Learned from Adoption to the Regulation of the Surrogacy Industry's Global Marketing of Children, 43 PEPP.L.REV. 265, 339 (2016).

${ }^{153}$ Embryo Carrying Agreements Law (Approval of the Agreement and the Status of the Child), 57561996, SH No. 1577 (Isr.).

${ }^{154}$ Cyra Akila Choudhury, The Political Economy and Legal Regulation of Transnational Commercial Surrogate Labor, 48 VAND. J. TRANSNAT'L L. 1, 2 (2015)

${ }^{155} I d$. at 62 .
} 
the industry. Fertility doctors are likely to follow legal regulations as they would still make significant profits even with increased regulation. Intended parents want to ensure parentage rights and thus would be motivated to follow legal rules. Finally, the medical procedures involved in surrogacy require some degree of knowledge, technology, and lab facilities, which makes it difficult for many people who are not experts to engage in it and it is harder to go undetected than, for example, black markets for illegal sex detection using ultrasounds. While illegal practices may exist even if surrogacy is legalized and regulated, they will also exist if there was a full prohibition on surrogacy. Putting protections in place can, at the very least, lay the groundwork and create a framework for safe and non-exploitative surrogacy.

\section{Conclusion: Lessons for Public Interest Litigation}

One lawyer's quest to end surrogacy in India, a quest based on various media accounts she had seen that presented surrogacy as exploitative, empowered the Supreme Court to become an active voice in directing surrogacy policy at the executive level. Though we cannot be certain, the actions of the Supreme Court likely had some level of influence in the adoption of the November 2015 policy by the Ministry of Home Affairs denying visas to all foreigners seeking surrogacy as well as the formulation of the prohibitionist approach in the 2016 Bill. Throughout its creeping jurisdiction, however, the Court never heard from a single woman who was a surrogate.

The Court has made enormous positive change through many SAL cases. In the modern SAL cases where the correct legal solution is not so clear-cut, the Court should ensure that it gives adequate consideration to all sides of the issue. In particular, the Court should welcome and invite impacted parties to testify when they are considering issuing broad orders that could deny the right to livelihood and work to many women.

Lawyers that bring SAL cases should also self-regulate. A model of collaborative lawyering calls for lawyers to take the views and needs of the clients seriously in guiding litigation and litigation strategy. ${ }^{156}$ Even if they are not required to consult with the parties whose rights they claim have been violated, lawyers bringing SAL cases should do so as a matter of good practice. Indeed, this is not a novel notion: public interest organizations like Human Rights Law Network that bring numerous SAL cases typically always include the impacted parties as petitioners.

The Court and others who care about the well-being of women who engage in surrogacy do have cause to be concerned about the practice of surrogacy in India. The private contract model that prevails in India leads to unfair terms and risk allocation. If the government were to treat surrogates as laborers and regulate surrogacy contracts more closely, then they could provide for minimum fees and other protections through regulation. A strong regulatory body, possibly funded by the medical clinics, could enforce the regulations. The 2016 Bill is still pending in Parliament and may simply

\footnotetext{
${ }^{156}$ See, e.g., Gerald P. Lopez, REBELLIOUS LAWYERING: ONE ChICANO'S VISION OF PROGRESSIVE LAW PRACTICE (1992); Lucie E. White, Collaborative Lawyering in the Field? On Mapping the Paths from Rhetoric to Practice, 1 Clinical. L. Rev. 157 (1994-95).
} 
languish like the three prior bills on surrogacy. If Parliament adopts the 2016 Bill, it will likely be judicially reviewed by the Court. Regardless of what the Supreme Court's ultimate decision is, the Court should give former and current surrogates their day in court. 